\title{
Folic acid supplementation in the juvenile-pubertal period in rats leads to persistent tissue-specific changes in the expresison and methylation of the tumour suppressor gene BRCA1
}

\author{
L. J. Rhodes ${ }^{1}$, A. A. Jackson ${ }^{1}$, M. A. Hanson ${ }^{1}$, G. C. Burdge ${ }^{1}$ and K. A. Lillycrop ${ }^{2}$ \\ ${ }^{1}$ Faculty of Medicine, University of Southampton, Southampton, SO16 6YD, UK and ${ }^{2}$ Faculty of Natural and Environmental \\ Sciences, University of Southampton, Southampton, SO16 6YD, UK
}

Micronutrient intake has been shown to influence cancer risk at least in part by modifying the epigenome ${ }^{(1)}$. However, the effects of folic acid intake during critical phases of development on future cancer risk are not known. We investigated whether variations in folic acid intake in the juvenile-pubertal (JP) period in rats induced lasting changes in the expression of the tumour supressor gene BRCA1, which plays a key role in maintaining genome integrity ${ }^{(2)}$.

The study was carried out in accordance with the Home Office Animals (Scientific Procedures) Act (1986). Female Wistar rats were fed a modified AIN93M semi-purified diet containing either $1 \mathrm{mg} / \mathrm{kg}$ feed folic acid (folate adequate (AF)) or $5 \mathrm{mg} / \mathrm{kg}$ feed folic acid (folic acid supplemented, FS) for $28 \mathrm{~d}$ from PN28 to PN56. After this period all rats were given AIN93M supplemented with $1 \mathrm{mg} / \mathrm{kg}$ folic acid. Tissues were collected on PN84. mRNA expression measured by real time RT PCR ${ }^{(3)}$ and BRCA1 promoter methylation was measured by sodium bisulphite pyrosequencing ${ }^{(4)}$.

JP folic acid supplementation induced tissue specific changes in BRCA1 mRNA expression that persisted beyond the period of supplementation. BRCA1 mRNA expression was significantly increased in adipose tissue, but decreased in muscle. Altered BRCA1 expression was accompanied by tissue-specific changes in the methylation of specific CpGs in its promoter. In adipose tissue, folic acid supplementation increased the methylation of $\mathrm{CpGs}-15,+14,+33$ and +47 , while in muscle there was an increase in methylation at $\mathrm{CpG}+33$.

\begin{tabular}{|c|c|c|c|c|c|}
\hline & \multicolumn{2}{|c|}{ Control AF $1 \mathrm{AF}$} & \multicolumn{2}{|c|}{ Control FS } & \multirow[b]{3}{*}{$t$-test $(p)$} \\
\hline & Mean & $\mathrm{SD}$ & Mean & SD & \\
\hline & \multicolumn{4}{|c|}{ BRCA1 mRNA expression $(\Delta \Delta \mathrm{Ct})$} & \\
\hline Adipose & 0.86 & 0.21 & 1.42 & 0.62 & 0.02 \\
\hline Muscle & 1.15 & 0.26 & 0.45 & 0.27 & 0.0001 \\
\hline \multicolumn{6}{|c|}{ BRCA1 DNA methylation ( $\%$ methylation) } \\
\hline Adipose CpG - 15 & 3.4 & 0.51 & 5.83 & 0.75 & 0.0001 \\
\hline Adipose $\mathrm{CpG}+14$ & 2.8 & 0.42 & 3.83 & 0.96 & 0.01 \\
\hline Adipose $\mathrm{CpG}+33$ & 8.4 & 1.43 & 11.0 & 3.54 & 0.05 \\
\hline Adipose $\mathrm{CpG}+47$ & 3.4 & 0.84 & 8.00 & 2.65 & 0.01 \\
\hline Muscle CpG - 15 & 4.00 & 1.85 & 3.40 & 2.25 & NS \\
\hline Muscle CpG + 14 & 2.57 & 1.27 & 1.57 & 0.1 .51 & NS \\
\hline Muscle $\mathrm{CpG}+33$ & 8.76 & 0.88 & 11.1 & 2.79 & 0.03 \\
\hline Muscle $\mathrm{CpG}+47$ & 4.12 & 0.64 & 5.00 & 1.59 & NS \\
\hline
\end{tabular}

These data show that FA supplementation induced tissue-specific changes in the expression and methylation of BRCA1 which persist beyond the period of feeding the modified diet. This suggests that altered epigenetic regulation of BRCA1 is one possible mechanism by which folic supplementation, at least during the JP period, may modify cancer risk. Differences in the effect of folic acid between tissues may have implications for understanding variations in the effectiveness of folic acid supplementation in cancer prevention between disease types and clinical trials ${ }^{(5)}$.

1. Jang H, Mason JB \& Choi SW (2005) J Nutr 135, 2967S-2971S

2. Gudmundsdottir K \& Ashworth A (2006) Oncogene 25, 5864-5874.

3. Lillycrop KA, Phillips ES, Jackson AA et al. (2005) J Nutr 135, 1382-1386.

4. Lillycrop KA, Phillips ES, Torrens C et al. (2008) Br J Nutr 100, 278-282.

5. World Cancer Research Fund/American Institute for Cancer Research (2007) Food, nutrition, physical activity and the prevention of cancer: A global perspective. Washington DC: AICR; 